\title{
Remote education: parents' challenges in teaching during the pandemic
}

Thalyta Freitas dos Santos Laguna 1

iD https://orcid.org/0000-0002-4227-0020

Tanandra Hermanns 2

(iD https://orcid.org/0000-0002-2568-2330

Ana Claudia Pinto da Silva 3

(iD https://orcid.org/0000-0002-2777-6023

Liana Nolibos Rodrigues 4

iD https://orcid.org/0000-0001-5024-321X

Josiane Lieberknecht Wathier Abaid 5

(iD) https://orcid.org/0000-0002-5746-5349

1-3 Departamento de Psicologia. Universidade Franciscana. Rua dos Andradas, 1614. Centro. Santa Maria, RS, Brazil. CEP: 97.010-032. E-mail: thalytalaguna@gmail.com 4,5 Departamento de Saúde Materno Infantil. Universidade Franciscana. Santa Maria, RS, Brazil.

\begin{abstract}
Objectives: to characterize the teaching-learning process of children in early childhood taught by their parents and/or caregivers in remote educational mode, in different social contexts, during the COVID-19 pandemic.

Methods: a bibliographic study was carried out through a qualitative research in three VHL, Lilacs and Scielo databases. The descriptors Children, Pandemic, Caregivers, Distance education and Mental health were used. The sample was composed of 35 materials.

Results: it was observed that countries presented problems in its educational system and that their situation also aggravated, such as in Brazil. Schools should try to mitigate the impact of the confinement, based on the recommendations that aim to consolidate what has been learned and interrupt the teaching of new content, eliminating the pressure on parents and guardians who assist students at this time. It is known that there is a lack of preparation of these caregivers, since the vast majority do not have materials or available time, because of home office, making remote learning difficult. The psychological impacts of remote learning - stress, fear, decreased performance and frustration are noticeable in everyone who is involved. Thus, the coping strategy focused on the problem can prevent the worsening of symptoms in mental health.

Conclusion: it is expected to promote future reflections according to the theme through Psychology.

Key words Home education, Psychological impacts, Parenting
\end{abstract}




\section{Introduction}

Coronavirus, responsible for thousands of people's death worldwide, is the causer of severe respiratory syndromes that placed the population in an emerging state of health. 1 The new virus emerged in 2019 in Wuhan, China, can be transmitted by droplets of saliva, sneezing, coughing, nasal secretion, contaminated objects or surfaces, such as doorknobs, tables, cell phones, toys, and by a simple handshake. ${ }^{2}$ In view of the situation that has gripped the world, physical distancing was one of the measures taken by the governments in all the countries, with the main intention of mitigating the spread of the virus.

With an increasing rate of infected people, criticism of this strategy has gained prominence, since physical distance was imposed by the pandemic, highlighting a series of problems that affect different areas, such as the economy and education. ${ }^{3}$ Around the world, all the institutions, from primary schooling to higher education, remained temporarily closed, a factor that impacted the lives of 1.5 billion students in 174 countries. 4 However, it is inferred that there was no determined time for face-to-face classes to remain suspended and schools to remain closed, and that face-to-face classroom activities has returned gradually, according to the government strategy in each country.

According to this matter, the UN highlighted that the temporary closure of these institutions has the main purpose of protecting everyone, since in the classroom they would take a greater risk of contamination and would be vectors for the virus to spread in their homes. However, this measure directly affects the education, since it could mean, above all, the interruption of the learning cycle. ${ }^{2,4}$

In this regard, the Ministry of Education ${ }^{5}$ has positioned itself in order to seek solutions that can guarantee learning can be continued with the least possible impact, authorizing, for example, remote learning and the distribution of the workload over a period, different from the 200 school days provided by law. No less important, the Brazilian Federal Government sanctioned the Law number 13.987 that authorizes the distribution of school meals to parents and guardians, since many students who attend public schools rely almost exclusively on this food on daily basis. 6

Therefore, the current situation is a great paradox, since the technological solutions are available for remote classes, it seems to be the best way to solve the problem, the lack of face-to-face classes, in which they may highlight and increase even more the differences of equity in the education, while schools are closed, part of the population that attends them would be subject to inequality and poverty of learning, especially the continuity of learning is guaranteed to some and denied to others. ${ }^{7}$

The current global scenario has highlighted problems that have long existed in Brazil and that corroborate the deficits in student learning: social and economic issues directly influence the learning outcome, since the students, in addition to all they already have experienced, they will now have to adapt to the reality of an unprepared educational system to help them face a new reality. ${ }^{8}$ The lack of basic social structure that affects many families was highlighted during the pandemic, since there was a breach of the "educational contract" that establishes the rights and duties of all those involved in the educational community. 9

Aside from all the issues mentioned so far, it is worth pointing out that those who are responsible, parents, and caregivers in general, in their majority, do not have the adequate preparation required to homeschool children, which involves, among other factors, abilities to teach, knowledge, and skills that provide the correct education in remote mode. 7

It is important to highlight that the difficulties presented above, regarding the caregivers as teachers, is an issue discussed for many decades by pedagogy and psycho-pedagogy professionals. Learning depends on the existing posture between the learner and the teacher, that is, to become a teacher, you need to open up to let the learning process happen. 10

From this perspective, the learner needs an adult who is willing to teach and believes in the child's potential, as well as providing autonomy and authorship to show what they already know and to develop new knowledge. It is important to emphasize that the teaching and learning process has a historical construction, in which social, biological, emotional, and affective aspects are taken into consideration. ${ }^{11}$

Amid in this atypical scenario in which the population finds itself, the difficulties presented in the educational context may be one of many triggers of psychological implications and may generate major risks to the mental health of all of those involved in the process, including symptoms of stress, anger, irritability, and among others. 12

The objective of the present study is to characterize the teaching-learning process of children taught by their parents and/or caregivers in remote educational mode, in different social contexts, during the COVID-19 pandemic. 


\section{Methods}

This study was based on the guiding question "How has remote educational mode on children from different social backgrounds been during the pandemic?" The search for materials was conducted in a three-month period between May and July 2020 based on the narrative literature review, whose main purpose is to describe and discuss the development of the state of the art from a theoretical point of view. This review includes analysis techniques, aiming to obtain indicators, whether it is quantitative or not and may allow the inference of content and knowledge. 13

Data collection was carried out through scientific articles extracted from national and international journals in the Virtual Health Library (VHL), Latin American and Caribbean Literature on Health Sciences (Lilacs) and Scientific Electronic Library Online (SciELO) platforms, in addition to portals such as the Ministry of Education and Health and the World Health Organization.

The descriptors used were Children, Pandemic, Caregivers, Distance Learning, and Mental Health. Thus, the simultaneous crossing between them was performed and the Boolean "AND" was used for the searches. The same descriptors were used for the three platforms.

Finally, the content analysis was performed, which presents the following sequence: organization, coding, categorization, treatment, and interpretation of the results. ${ }^{13}$ The findings found in the literature were discussed in three respective categories: (1) Teaching and learning in different social contexts: a reflection; (2) Parents as teachers: main challenges; (3) Home classroom: psychological impacts of remote learning for parents and children.

\section{Results and Discussion}

In the VHL (67), Lilacs (24) and Scielo (47) databases, only the materials that answered the guiding question and the objectives of this study were selected. For this review, 35 documents were included, of which 26 are articles published in national and international journals, four are materials from the Ministry of Health, three from the Ministry of Education, and two are from the World Health Organizations. The findings were compiled into three categories extracted by the content to meet the objectives, presented and discussed below.
Teaching and learning in different social contexts: a reflection

During the COVID-19 pandemic, all the attention has been focused on mitigating the spread of the disease, since great are the impacts in all spheres. In just a few months, the population in the world found themselves facing a scenario that forced the creation of a series of adaptations, including education, since millions of students suffer the impact of the pandemic in the educational system. 4

The pandemic highlighted the reality of the educational systems in different countries around the world. ${ }^{8}$ Brazil is indicated as a country with striking problems in the educational system in one of the studies that were analyzed - which investigates the structure, production, efficiency, and effectiveness in the educational system before the pandemic - and, in this sense, the authors of this finding discussed functional illiteracy, educators' low salaries, poor infrastructure of the schools, violence of all kinds, and, nevertheless, worsening results in external and internal evaluations. 14

About this controversial issue, since before the pandemic, some studies have already pointed out that the above-mentioned factors along with many others are responsible for the dissatisfaction of many parents and caregivers about the quality of education in Brazil, compared to other countries. 15,16,17 The reflection of the mismanagement of public coffers is printed, among many other scenarios, in education, and the pandemic of the new virus has arrived to reiterate an even greater crisis that shows, above all, an educational system without sufficient structure to support parents and/or caregivers and children. ${ }^{8}$

When relocating the educational process from school to home, the great disparity between upperand lower-class families became evident, since a large part of the public that is classified as being from the less favored classes, especially in the third world countries, live in precarious conditions. Not least, they lack material structure, such as technology, space, light, temperature, and resources such as time, pedagogical skills, content knowledge, emotional stability, and many times, even food. 8,9

About this disparity, studies mentioned that most middle-class families in some countries, such as Spain, have technical conditions to support the apprentices, while other social groups do not have the means, resources and skills to do so, and not least, some are not even at home during the period of confinement, now more strictly applied to students. 18 A number of factors can highlight this disparity that will certainly have an impact on the future of learners in several countries around the 
world: some families are single-parent and do not have support for childcare, others work in the front lines during the pandemic and often come home and interact with the rest of the household members, some do not even have a computer and broadband to have quality access to the content passed on by the schools, and among others. 9

In this regard, the $\mathrm{UN}^{4}$ has stated that the interaction that occurs between teachers and students also contributes to the learning process and that its absence may not only contribute to an increase dropout rates but may also generate a significant loss of future human capital. While those who live in vulnerable situations are unable to access computers and Internet, students who attend private schools are somehow prepared to continue their education, and this highlights the great educational disparity that affects many nations. 18

It is worth mentioning that in the midst of the pandemic and the educational crisis that affects families of different classes in different ways, many schools are not used to remote education and are not adequately prepared to instruct families and teach students properly. 7 When face-to-face classes were replaced by the remote format, one must consider that the educational disparity - mentioned above, often stems from the disparity between the socioeconomic levels of the countries, the different network connectivity in the regions of Brazil, such as rural and urban centers, and the scarcity of infrastructure, factors that can negatively impact education. ${ }^{4}$

The Brazilian Ministry of Education, 2 through its website, has disclosed some measures that are being taken during the pandemic scenario. Among them is an online course for literacy coaches, in which teachers, literacy assistants, pedagogical coordinators, school principals, and parents can participate for free. The main objective of the available tool is, therefore, to teach all those involved techniques and methods that can be used in the process of teaching children in the first and second grades in elementary school and reinforcing children in the third grade, also in elementary school.

Although we understand the efforts of the Ministry of Education to mitigate the damage of teaching in remote mode, we are faced with what one of the studies points out to be a "digital gap", since, in order to have the minimum use of the contents foreseen in the school menu, efforts should be directed to ensure that all students, without exception, have access to Internet, thus allowing all of them to access digital platforms and the educational content. ${ }^{7}$ This is one of the gaps in school education that exist due to the socioeconomic conditions strongly discussed before the pandemic period. 14

The pandemic and social distancing - which imposed remote education - gave the society the opportunity to see that cultural and social capital of families are completely different from those with low purchasing power and those in upper middle class and upper class; while some schools are active and ask for a variety of school tasks, others are completely inactive. 18

Schools move back and forth between "capabilities and capacities", i.e., while some schools can offer adequate and leveled digital learning, monitor the involvement of students and also their parents in school tasks, and provide feedback that can enhance results, others do not even have the resources and training to do so. 7 The same is true if we observe children in different scenarios: while some have access to museums, movies, theater, travel, and technology, active agents that fill the learning baggage, others have never had access to such cultural capital. 8

One of the studies on the subject points out that "all these students lack social structure that enables the oxygen of learning to reach their lungs. They lack educational respirators". 9 That is, the lack of educational resources, coupled with all the difficulties encountered by children, is the fact that their guardians often do not even have a basic education, which makes it impossible to provide guidance aimed to construct knowledge at childhood. ${ }^{8}$

Given the inequalities present in the current pandemic moment, the objective of the school should be to try to mitigate the impact of confinement, in order to reduce educational disparities, considering the possible needs of disadvantaged students. ${ }^{19}$ In this sense, offering recommendations that are adaptive to the realities present in the families is a recommended attitude, since it aims to consolidate what has been learned and interrupt the teaching of new contents, and thus, eliminate the pressure to meet educational goals. Moreover, after the period of social distancing, a possible diagnosis by the educators of what was learned during this time is necessary, reviewing the content in order to fill possible learning gaps. 20

\section{Parents as Teachers: Key Challenges}

With the suspension of classroom activities in schools due to the pandemic, many families face challenges in supporting school activities in a remote format. The situation affects people of all different ages, but families with children in early childhood ( 0 to 6 years old) face even greater challenges, since 
this is the phase when literacy begins. Thus, adaptations are required to a new reality that favors remote teaching activities. ${ }^{21}$ Thus, in addition to home office and house chores, parents and/or guardians are charged with the role of being teachers at home, becoming teachers of their own children.

The decision to continue school activities at home implies that families take over the formal education of the children. However, this solution was designed for homes with material conditions and time to perform it, not taking into account economically and socially insufficient homes, where adult members work or have limitations such as functional illiteracy. 19 Nevertheless, it is known that most caregivers do not have teacher training, and even if they did, they are seen by their children as caregivers and not their school teacher. ${ }^{21}$ In this regard, one of the studies analyzed stated that:

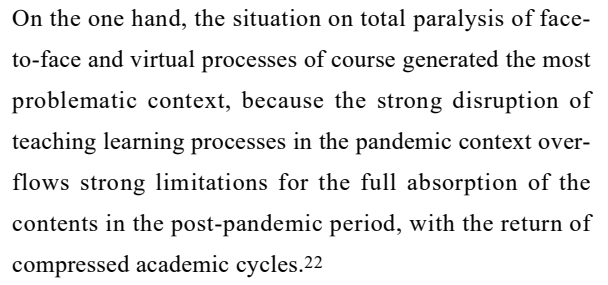

Another study stated that the pandemic scenario ended up imposing on families and students an adaptation of classroom teaching, that is, parents, teachers, and students are quite confused because they are not adequately prepared for situations like this. It also states that what is being experienced is a remote activity on an emergency basis, in which students are being educated through video classes. ${ }^{23}$

In the context of basic education, the new teaching model has been loaded with challenges for parents and caregivers. ${ }^{22}$ Aware of the difficulties, the Ministry of Health24 through the Saúde Brasil portal (Health Brazil), published the "Diary of a Pandemic", which brings significant content in order to guide parents and children during the pandemic. The suggested orientations range from how to explain the concept of coronavirus through playful language, to the suggestion of games, games, physical exercises, small household chores, and appropriate activities for the children's educational stage.

The target audience of the emergency remote activities are children in the construction phase of knowledge and autonomy. For better development and learning, the child needs to live with people outside its family circle in order to better develop its skills and its ability to live with others. 23 In addition to the family nucleus and other adults, this period of education aims to propose exploratory, motor, sensory, and affective activities, in addition to an organic and progressive set of essential learning that all students must develop throughout the stages and modalities of Basic Education. 25

The beginning of the literacy process is an example of learning acquired during early childhood, since the development of the language, the child begins to acquire the ability to interact and interpret codes that will help in the literacy process. 26 The first contact with letters is a challenge that requires the monitoring of a pedagogical professional, but currently this is impossible due to social distancing. The Ministry of Education, 27 through the Secretaria de Alfabetização (Sealf) (Secretary of Literacy), created the Politica Nacional de Alfabetização (PNA) (National Literacy Policy), instituted by the Decree Number 9,765, April 11, 2019 , recognizing the importance of early childhood for the child's linguistic development and fighting illiteracy throughout the Brazilian territory. In it, there is some advice for teachers and caregivers to facilitate the literacy process.

During early childhood, literacy, a set of knowledge, skills, and attitudes related to reading and writing, developed before literacy, begins to emerge in the child's life, and is fundamental for literacy. 28 By listening to different kinds of stories, reciting poems, listening and singing to songs, and becoming familiar with materials such as magazines, books, and newspapers, the child starts to recognize letters, names, and sounds and tries to represent them in writing, identifying all the graphic signs that surround them. Thus, during emergent literacy, the child can experience, in a playful way, experiences and knowledge about writing and reading appropriate for the age, either formally or informally, even before learning to read and write. 27

The role of the family in the child's success in learning to read and write is relevant and can be encouraged with shared readings of stories, playful and didactic games, aiming to expand vocabulary and understand the oral language. In addition, it awakens the imagination and strengthens the family bond. 29 Therefore, the active role of the family in helping the school in the current pandemic moment can minimize possible educational difficulties.

It is in the childhood period that parents act as regulators and role models of how to deal with the demands and stressful events that may occur; thus, a parenting characterized with affection, reciprocity, responsiveness, and positive communication is relevant in the pandemic context. 30 It should be noted that there are many realities in which parents or 
guardians, in addition to not being able to effectively monitor the children, also do not have a support network with whom they can leave their children at home, such as grandparents, babysitters, close relatives, and among others. This factor contributes significantly to the children not receiving the necessary support during these stressful events. Therefore, it is important to note that, many times, these children end up accompanying their caregivers to work or even staying home alone.

In February 2020, the Brazilian government passed a law number $13.979,31$ in order to deal with the pandemic. According to the legislation, workers who are absent due to quarantine (40 days) or isolation (14 days) will have their absences justified. However, there is nothing about the possibility of home office, and it is up to the company to decide whether to adopt it or not, a factor that often makes parents have to make a decision: leave their children at home alone, but ensure their livelihood, or stay with them and put their source of income at risk. This decision goes against the child's rights.

At the same time, that it values the special protection of these minors and seeks to guarantee that they are raised under the care of their parents, seeking to ensure that they are supported with decent food, education, and health care, aspects that can hardly be guaranteed with excellence if the caregivers are unemployed. 32 It is necessary, then, to have an empathic look at these families, in addition to providing a plausible solution for this problem.

It is important to consider that the overload of the family members due to the excess of responsibilities, either professional or domestic, added to the children's demands, the lack of adequate space for teaching, among other factors arising from the atypical situation in which the world finds itself, has provided parents, family members, and children with an excessively high level of demand that may converge in high levels of frustration as well. ${ }^{33}$

\section{Classroom at home: the psychological implications of remote teaching on parents and children}

In view of the current scenario that has led to social distancing in all the countries of the world, many review studies have been published in order to identify the possible effects of quarantine on people's lives. ${ }^{34}$ It is known that, in order to mitigate the spread of the virus, a series of measures have been taken, some of them extreme, including the isolation of suspect cases, the social distancing of elderly people and other risk groups, the closing of schools and universities, and the quarantine of the entire population. ${ }^{12}$ In the midst of the crisis, the primary focus ends up being the fight against pathogens and the preservation of physical health, but much is underestimated when it comes to mental health. 35

Experts on the topic, based on some 24 studies in different settings involving isolation and distancing, state that "the main factors identified by stress, stand out the effect of the length of the quarantine period, fears about the virus or infection, frustration, decreased income, inadequate information, and stigma," 34 increasing the psychological impacts on children and the families. Historical events such as quarantine can negatively affect human development as it promotes a disordered and consequently stressful environment that is reflected in the family system and the children's development. 36

Besides the psychological consequences, the physical distance deprives children of the important socialization with peers, considerable learning for human development, such as: share play experiences, communication, cooperation, coexistence with differences, facing and sharing decisions, and conflict resolution. 37 Furthermore, with the remote education installed in Brazil, the home became a classroom and the parents became teachers, causing a chaotic and stressful context. In this sense, the home became a place with uncertainties and lack of foresight to return to social relations outside this environment, becoming an anxiogenic aggravating factor. 36

Within the pandemic context, society is exposed not only to the advance of the disease, but also to the excess of available information that often confuses those who hear it and drives psychological illness. ${ }^{38}$ Thus, the Pan American Health Organization 39 evidence that a pandemic of the magnitude of COVID-19 can bring about a series of psychosocial disturbances that exceed the population's coping capacity, since all of them suffer from anguish to a greater or lesser degree. "Essentially, an increase in the incidence of psychological disorders is estimated (between one third and half of the exposed population may suffer some psychopathological manifestation, according to the magnitude of the event and the degree of vulnerability)."

Therefore, the pandemic requires from the individual the mobilization of stress coping strategies in an adaptive way, with the intention of avoiding the toxic stress that this adversity can generate, 36 establishing the three basic psychological needs, innate and universal, that are affected during the pandemic, 
which are: relationship - feeling loved in stable relationships; competence - having control to manage challenges and meet goals; and autonomy - making decisions and assuming the respective consequences. ${ }^{40}$ Furthermore, the toxic stress - different from the positive and tolerable - refers to a strong, frequent and prolonged stress, for which the body lacks protection, mechanisms capable of mitigating the negative effects, a factor that can generate exhaustion and hyper vigilance in the individuals who experience it. 36

Thus, coping - which can be characterized as a set of cognitive and behavioral efforts with the purpose of dealing with internal or external demands that derive from stressful situations that cause overload on the individual - can be an alternative way of coping with toxic stress. 41 However, considering that the adaptive coping capacity can be threatened in this period, the most commonly used coping strategies are: the search for a support network, the escape, the attempt to solve the problem, or the distraction.

The less adaptive coping responses may increase the child's vulnerability, since the child is in development of his/her self-regulation skills - planning, focusing, multitasking. Thus, in the development process of the children's coping, some strategies are common, such as: "the search for support, the problem solving and instrumental action, the escape and, when this is not possible, the distraction".36 Furthermore, according to the author, the support and promotion of autonomy through the caregivers will enable the child's self-confidence to deal with future problems.

\section{Final considerations}

The present study aimed to identify how the teaching/learning of early childhood children taught by their parents in remote education has been constituted in different social contexts during the pandemic of the new coronavirus. The results showed the difficulties inherent in the learning process during the pandemic, since the achievement of better results regarding to the adaptation in remote education is linked to economic aspects and access, both to technologies and to the support network. There are also major challenges, such as the classroom adaptation to the remote mode, the parents' lack of preparation to act as teachers, as well as the absence of available technologies to support and fill the gaps that remote teaching has evidenced.

Thus, there is a great abyss arising from social differences, since a large part of the population in developing countries, such as Brazil, is socially vulnerable, and it can be concluded that the continuity of learning is guaranteed to some and denied to others. Moreover, an educational system without enough structure to support parents and/or caregivers is also responsible for the dissatisfaction of many parents and caregivers about the quality of education in Brazil.

Physical isolation causes loss of external role models in the social context, such as school and the work environment. In this perspective, with the recommendations concerning the coping with the coronavirus pandemic and with the social protection measures indicated by the World Health Organization, families can possibly be supported in facing the psychological and educational needs mentioned.

In the current stressful context caused by the pandemic, the person may manifest maladaptive strategies such as denial, avoidance, and fanciful or magical thinking. Therefore, the search for reliable and quality evidence-based information and the planning of actions aimed at dealing with the possibilities available for resolving possible difficulties are more adaptive coping methods, promote a feeling of self-efficacy, and avoid helplessness and the emotions that accompany it, such as fear and pessimism.

Moreover, in the educational field, children belonging to more vulnerable contexts may suffer a pedagogical deficiency, since the Brazilian socioeconomic inequality is a reality, and consequently, the educational system does not have enough structure to support the guardians and the children. Scarce means, functional illiteracy, and lack of didactic skills further aggravate the educational disparities present in Brazilian society. Thus, the purpose of the schools should try to mitigate the impact of confinement, with recommendations that are adaptive to the realities of the different Brazilian families, also aiming to preserve their mental health of all of those involved.

However, this study is restricted to the scenario in which we live, containing limitations as to the eventual post-pandemic consequences, since the impacts are not yet known. It is important to point out that countries have organized themselves quickly to enable further learning. Therefore, it is necessary that institutions and governmental agencies be prepared for possible unforeseen events.

Thus, we hope to promote future reflections on the theme through Psychology, since it is of utmost importance to discuss the teaching activity that was imposed on parents in the times of this pandemic, as 
well as the psychological impacts that this situation is generating.

\section{Authors' Contributions}

All the authors contributed equally in all the development of the work, from research tod writing and approved the final version of the article.

\section{References}

1. Arentz M, Yim E, Klaff L, Lokhandwala S, Riedo FX, Chong M, Lee M. Characteristics and Outcomes of 21 Critically Ill Patients With COVID-19 in Washington State. Jama. 2019; 323 (16): 1612-4.

2. Brasil. Ministério da Educação. Coronavírus: saiba quais medidas o MEC já realizou ou estão em andamento. 2020 [acesso 10 mai 2020]. Disponível em http://portal.mec.gov.br/component/content/article?id=867

3. Ferrari A, Cunha AM. A pandemia de Covid-19 e o isolamento social: saúde versus economia. 2020 [acesso $10 \mathrm{ma}$ 2020]. Disponível em: https://www.ufrgs.br/coronavirus base/artigo-a-pandemia-de-covid-19-e-o-isolamento-socialsaude-versus-economia/

4. Brasil. Nações Unidas. A experiência internacional com os impactos da COVID-19 na educação. 2020 [acesso 11 ma 2020]. Disponível em: https://nacoesunidas.org/artigo-aexperiencia-internacional-com-os-impactos-da-covid-19na-educacao/

5. Brasil. Ministério da Saúde. Coronavírus (Covid-19). 2020 [acesso 11 mai 2020]. Disponível em https://coronavirus.saude.gov.br/sobre-a-doenca\#o-que-ecovid

6. Brasil. Lei $\mathrm{n}^{\circ} 13.987$ de 7 de abril de 2020. Altera a Lei $\mathrm{n}^{\circ}$ 11.947 , de 16 de junho de 2009, para autorizar (...) a distribuição de gêneros alimentícios (...) aos pais. Diário Oficial da União, 7 de abril de 2020. Edição 67-B, Seção 1Extra, p. 9; [acesso 10 nov 2020]. Disponível em:https://www.in.gov.br/web/dou/-/lei-n-13.987-de-7-deabril-de-2020-251562793?inheritRedirect=true\&redirect $=\% 2 \mathrm{Fweb} \% 2 \mathrm{Fguest} \% 2 \mathrm{Fsearch} \% 3 \mathrm{FqSearch} \% 3 \mathrm{D} 13.987$ $\% 252 \mathrm{C} \% 2520 \mathrm{de} \% 25207 \% 2520 \mathrm{de} \% 2520$ abril $\% 2520 \mathrm{de} \% 2$ 5202020

7. Moreno JM, Gortázar L. Schools' readiness for digita learning in the eyes of principals. An analysis from PISA 2018 and its implications for the COVID19 (Coronavirus) crisis response. Education for Global Developement. [Internet]. 2020 [cited 2020 May 10]. Available from: https://blogs.worldbank.org/education/schools-readinessdigital-learning-eyes-principals-analysis-pisa-2018-and-its

8. Avelino WF, Mendes JM. A realidade na educação brasileira a partir da Covid-19. BolConjunt.2020; 2 (5): 5662.

9. Martín JM, Rogero J. El coronavirus y la asfixia educativa: el confinamento dejasinprotección a lainfancia más vulner- able. [Internet]. 2020 [acesso 12 mai 2020]. Disponible en: https://www.agenciasinc.es/Opinion/El-coronavirus-y-laasfixia-educativa-el-confinamiento-deja-sin-proteccion-ala-infancia-mas-vulnerable

10. Fernandez A. Os idiomas do aprendente: análise das modalidades ensinantes com famílias, escolas e meios de comunicação. Porto Alegre: Artmed; 2001.

11. Vygotsky LS. A Formação Social da Mente: O Desenvolvimento dos Processos Psicológicos Superiores. São Paulo: Martins Fontes; 2003

12. Schmidt B, Crepaldi MA, Bolze SDA, Neiva-Silva L, Demenech LM. Mental health and psychological interventions during the new coronavirus pandemic (COVID-19). EstudPsicol. 2020; 37: 1-13.

13. Bardin L. Análise de conteúdo. São Paulo: Edições 70; 2016.

14. Fleury, MT. Mattos, MIL de. Sistemas educacionais comparados. Estud Av. 1991; 5 (12): 69-89.

15. Andrade ÉP de. Educação Domiciliar: encontrando o Direito. Pro-Posições. 2016; 2 (83): 172-92.

16. Cury CRJ. Homeschooling ou educação no lar. Educ Rev. 2019; 35: e219798.

17. Vasconcelos MCC. Educação na casa: perspectivas de desescolarização ou liberdade de escolha? Pro-Posições. 2017; 28 (2): 122-40.

18. Bonal X, González S. Confinamiento y efectoescuela. Catalunya, Espanha. [Internet]. 2020 [acesso 15 mai 2020]. Disponibleen:

https://www.elperiodico.com/es/opinion/20200406/efectocoronavirus-desigualdad-escuelas-xavier-bonal-sheilagonzalez-7919442

19. Rogero-García J. La ficción de educar a distancia. RevSociolla Educ.2020; 13 (2): 174-82.

20. Guizo BS, Marcello FA, Müller F. A reinvenção do cotidiano em tempos de pandemia. EducPesq São Paulo. 2020; 46:1-18.

21. Torres ACM, Costa ACN, Alves LRG. Educação e saúde: reflexões sobre o contexto universitário em tempos de COVID-19. [Internet]. 2020 [acesso 10 nov 2020]; 1-11. Disponível em: https://doi.org/https://doi.org/10.1590/ SciELOPreprints.640.

22. Martins SE. Coronavírus e educação: análise dos impactos assimétricos. BolConjunt. 2020 [acesso 10 mai 2020]; II(5):2020. Disponível em: www.revista.ufrr.br/bocabole- 
timdeconjuntura

23. Joye CR, Moreira MM, Rocha SSD. Distance Education or Emergency Remote Educational Activity: in search of the missing link of school education in times of COVID-19. Res Soc Dev. 2020; 9 (7): e521974299.

24. Brasil. Ministério da Saúde. Diário de uma pandemia: 5 dicas para orientar pais e crianças. [Internet]. 2020 [acesso em 10 mai 2020]. Disponível em: https://saudebrasil.saude.gov.br/eu-quero-me-exercitarmais/diario-de-uma-pandemia-5-dicas-para-orientar-pais-ecriancas

25. Brasil. Base Nacional Comum - BNCC. Mec. [Internet]. 2018 [acesso 10 nov 2020]; 600. Disponível em: http://basenacionalcomum.mec.gov.br/images/BNCC EI E F_110518_versaofinal_site.pdf

26. Silva AKA. Sobre a Teoria Vigotskiana e a Formação Docente. 2001 [acesso 10 mai 2020]; 11380-11392. Disponível em: https:/educere.bruc.com.br/arquivo/ pdf2013/8233 7087.pdf

27. Brasil. Ministério da Educação. Secretaria de Alfabetização. PNA Política Nacional de Alfabetização/Secretaria de Alfabetização. Brasília. 2019 [acesso 10 mai 2020]; 2019;54. Disponível em http://portal.mec.gov.br/images/banners/caderno_pna_final. pdf

28. Development EL. Developing early literacy. Literacy. 2008; 2 (1): $1-25$.

29. Movileanu L, Sima CC. Family literacy in Europe: using parental support initiatives to enhance early literacy development. Clare Sheahan AlgStichtWelzAppingedam. 2011 [cited 2020 May 10]; (8). Available from: http://www.nrdc.org.uk/wpcontent/uploads/2015/11/EC_Family-Literacy 0.11.zip

30. Muratori P, Ciacchini R. Children and the COVID-19 transition: Psychological reflections and suggestions on adapting to the emergency. Clin Neuropsychiatry. 2020; 17 (2): 131-4. Available from: https://pesquisa.bvsalud.org/global-literature-on-novelcoronavirus-2019-ncov/resource/en/covidwho-380324

31. Brasil. Ministério da Saúde. Lei n. 13.979. de 06 de fevereiro de 2020. Dispõe sobre as medidas para enfrentamento da emergência de saúde pública de importância internacional decorrente do coronavírus responsável pelo surto de 2019. [Internet]. 2020 [acesso 10 mai 2020]. Disponível em: https://www2.camara.leg.br/legin/fed/lei/2020/lei13979-6-fevereiro-2020-789744-

normapl.html\#: :text=EMENTA\%3A\%20Disp $\% \mathrm{C} 3 \%$ B5e $\% 20$ sobre $\% 20$ as $\% 20$ medidas,respons $\%$ C3\%A1vel $\% 20$ pelo $\% 20$ surto\%20de $\% 202019$.
32. Brasil. Estatuto da Criança e do Adolescente - Lei 8.069 de 13 de julho de 1990. Dispõe sobre o Estatuto da Criança e do Adolescente e dá outras providências. [Internet]. 2020 [acesso 18 mai 2020]. Disponível em: http://www.planalto.gov.br/ccivil_03/leis/18069.htm

33. Brasil. Ministério da Saúde. Saúde mental e atenção psicossocial na pandemia COVID-19. Fiocruz. 2020 [acesso 10 nov 2020]. Disponível em: https://portal.fiocruz.br/documento/saude-mental-e-atencao-psicossocial-na-pandemiacovid-19

34. Maia BR, Dias PC. Ansiedade, depressão e estresse em estudantes universitários: o impacto da COVID-19. Estud Psicol. 2020; 37: 1-8.

35. Ornell F, Schuch JB, Sordi AO, Kessler FHP. "Pandemic fear" and COVID-19: Mental health burden and strategies. Braz J Psychiatry. 2020; 42 (3): 232-5.

36. Linhares MBM, Enumo SRF. Reflexões baseadas na Psicologia sobre efeitos da pandemia COVID-19 no desenvolvimento infantil. Estud Psicol. 2020; 37: e200089.

37. Holmes EA, O'Connor RC, Perry VH, Tracey I, Wessely S, Arseneault L, et al. Multidisciplinary research priorities for the COVID-19 pandemic: a call for action for mental health science. Lancet Psychiatry. 2020; 7 (6): 547-60.

38. Pereira MD, Oliveira LC, Costa CFT, Bezerra CMO, Pereira MD, Santos CKA, et al. A pandemia de COVID-19, o isolamento social, consequências na saúde mental e estratégias de enfrentamento: uma revisão integrativa. Res Soc Dev. 2020; 9 (7): e652974548

39. OPAS/OMS Proteção Da saúde mental em situações de epidemias. [Internet]. 2009 [acesso 10 mai 2020]; p.1-26. Disponível em: https://www.paho.org/hq/dmdocuments/2009/Protecao-da-Saude-Mental-em-Situaciones-deEpidemias--Portugues.pdf

40. Bouffard L. Ryan RM, Deci EL. Self-determination theory. Basic psychological needs in motivation, development and wellness. New York, NY: Guilford Press. Rev québécoise Psychol. 2017; 38 (3): 231-4. Available from: https://www.erudit.org/fr/revues/rqpsy/2017-v38-n3rqpsy03258/1041847ar/

41. Maia Â, Sendas S, Lopes R, Mendes JM. A eficácia das estratégias de coping após um evento traumático: uma revisão sistemática. e-cadernos CES. 2016; 25: 64-82.

Received on September 29, 2020

Approved on March 30, 2021 